\title{
The Diversity of Bacteria Isolated from Antarctic Freshwater Reservoirs Possessing the Ability to Produce Polyhydroxyalkanoates
}

\author{
Slawomir Ciesielski • Dorota Górniak • \\ Justyna Możejko • Aleksander Świątecki • \\ Jakub Grzesiak • Marek Zdanowski
}

Received: 26 February 2014/ Accepted: 30 April 2014/Published online: 18 June 2014

(C) The Author(s) 2014. This article is published with open access at Springerlink.com

\begin{abstract}
The diversity of polyhydroxyalkanoates-producing bacteria in freshwater reservoirs in the Ecology Glacier foreland, Antarctica, was examined by a cultivation-dependent method. Isolated strains were analyzed phylogenetically by $16 S r R N A$ gene sequencing, and classified as members of Alpha-, Beta-, or Gammaproteobacteria classes. Polymerase chain reaction was used to detect PHA synthase genes. Potential polyhydroxyalkanoates (PHAs) producers belonging mainly to Pseudomonas sp., and Janthinobacterium sp. were isolated from all five sampling sites, suggesting that PHA synthesis is a common bacterial feature at pioneer sites. All Pseudomonas strains had the genetic potential to synthesize medium-chainlength PHAs, whereas some isolated Janthinobacterium strains might produce short-chain-length PHAs or mediumchain-length PHAs. It is the first report revealing that Janthinobacterium species could have the potential to produce medium-chain-length PHAs.
\end{abstract}

\footnotetext{
S. Ciesielski $(\bowtie)$

Department of Environmental Biotechnology, University of Warmia and Mazury in Olsztyn, ul. Sloneczna 45G,

10-718 Olsztyn, Poland

e-mail: slavcm@uwm.edu.pl

D. Górniak · J. Możejko · A. Świątecki

Department of Microbiology, University of Warmia and Mazury

in Olsztyn, ul. Oczapowskiego 1A, 10-719 Olsztyn, Poland

J. Grzesiak · M. Zdanowski

Department of Antarctic Biology, Institute of Biochemistry and

Biophysics, Polish Academy of Sciences, ul. Ustrzycka 10,

02-141 Warsaw, Poland
}

\section{Introduction}

A wide variety of taxonomically different groups of microorganisms are known to produce intracellular energy and carbon storage compounds, generally described as polyhydroxyalkanoates (PHAs) [1]. It has been shown that bacterial cells with a higher content of PHAs can survive longer than those with a lower PHAs content, because they can utilize their reserve material longer and more efficiently [7]. Therefore, it was stated that the accumulation of PHAs might increase the survival capabilities of these bacteria in extreme environments or when nutrient availability is poor [8].

PHAs are synthesized by many bacteria and archaea [31] when in environment carbon is available, but other essential nutrients are not. PHAs are commonly divided into two groups based on the number of constituent carbon atoms in their monomer units: short-chain-length (scl-) PHAs and medium-chain-length (mcl-PHAs). The former consists of monomers with 3-5 carbon atoms and the latter consists of monomers with 6-14 carbon atoms. The most commonly produced is polyhydroxybutyrate $\mathrm{P}(3 \mathrm{HB})$, an scl-PHA. The physical properties of individual PHAs depend on the composition of the monomer units. $\mathrm{P}(3 \mathrm{HB})$ is highly crystalline, whereas mcl-PHAs are elastic with low melting temperature [32]. These variations in the PHA polymer family create the potential for a vast array of applications [14].

PHAs are accumulated in intracellular granules. The surface of PHA granules is coated with phospholipids and proteins which play a major role in PHA synthesis, degradation, and even in the process of PHA synthesis regulation. The type of PHA produced and accumulated in the granules depends on the metabolic pathway of the particular microorganism. However, independently of the type of synthesized PHAs, the enzyme called PHA synthase always plays the main role [19]. 
Fig. 1 Map showing sampling location in the foreland of Ecology Glacier, King Georg Island, Antarctica. Sampling sites are characterized in Table 1. (Part of Admiralty Bay map modified from Pudełko

[17]

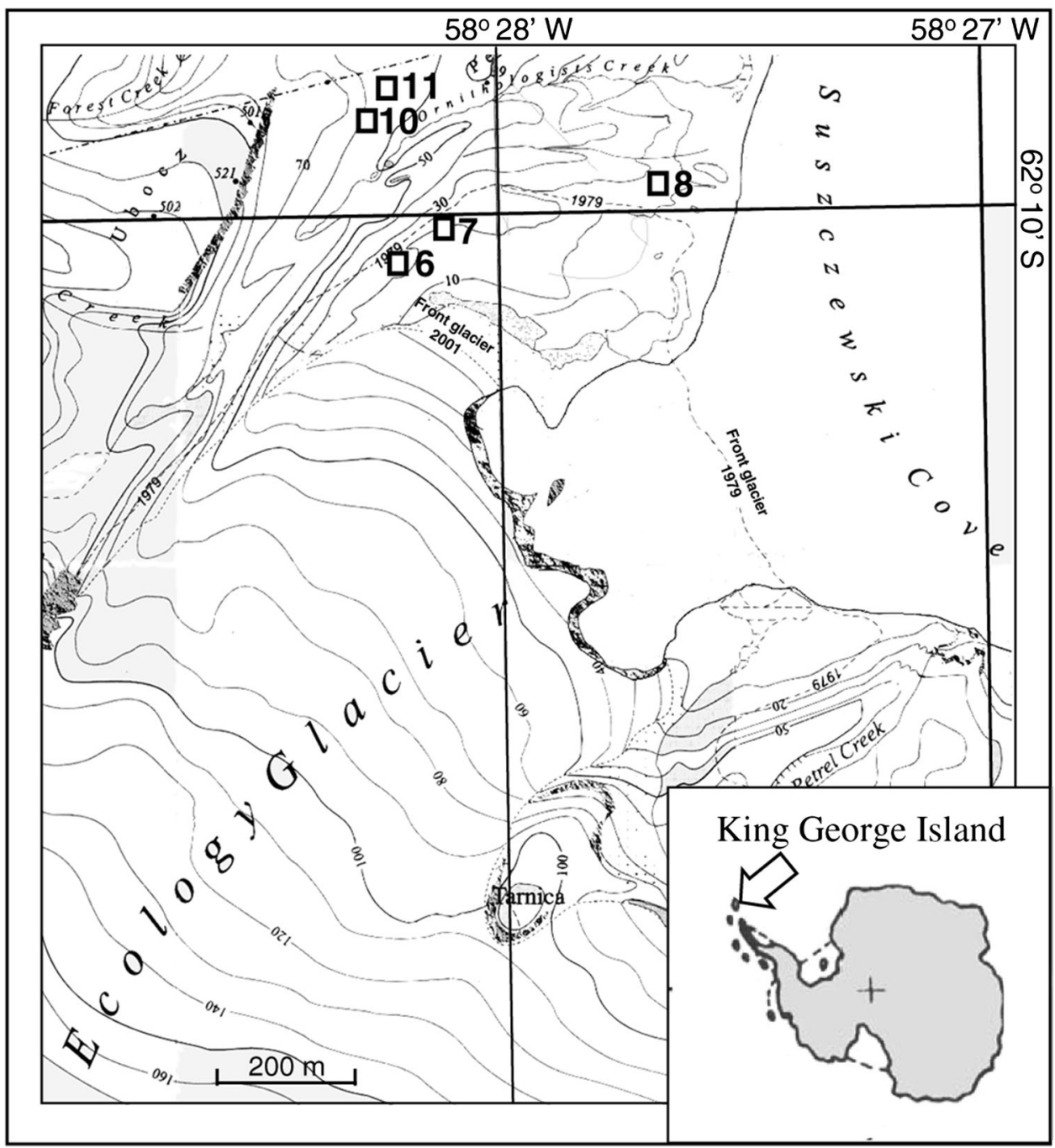

PHA synthases were classified into four classes, according to their substrate specificities and subunits organization. Classes I, III, and IV prefer to synthesize scl-PHA ( $p h a C$ gene), whereas the II class is responsible for mcl-PHA synthesis [20]. Class I of PHA synthase comprises enzyme consisting of single subunit, whereas classes III and IV comprise enzymes that consist of two different types of subunits. The II class of PHA synthase is also built by single subunit but it is coded by two forms of gene that are called phaCl and phaC2 [20]. The nucleotide composition of phaCl and phaC2 genes is very similar but their substrate specificity may differ [10].

Extremophiles inhabiting polar areas are a source of a novel enzymes, which have a great economic potential in many industrial processes, including agricultural, chemical, and pharmaceutical applications [33]. Especially, shallow Antarctic reservoirs influenced by the forces of variable trophic conditions are underexploited sources of microorganisms with biotechnological potential. As a result of selection pressures in these reservoirs, there is a potential for the discovery of novel biochemical pathways leading to
PHAs synthesis. Psychrotrophic bacteria, which are adapted to variable temperatures and to other fluctuating conditions such as low nutrient availability and low water quality, may offer important advantages for industrial PHAs production [9]. It is widely accepted that microorganisms from unusual environments provide not only valuable resources for exploiting novel biotechnological processes, but also serve as models for investigating how these biomolecules are stabilized when subjected to changing conditions [12]. The main purpose of this study was to determine whether bacteria inhabiting freshwater reservoirs in glacier forefield areas have the potential to synthesize PHAs.

\section{Materials and Methods}

\section{Collection Sites}

Samples of water and mats were collected in summer of 2011 year from five, shallow freshwater reservoirs and one 
Table 1 Characteristics of sampling sites

\begin{tabular}{|c|c|c|c|c|c|}
\hline \multicolumn{6}{|l|}{ Sampling site } \\
\hline Variables & 6 & 7 & 8 & 10 & 11 \\
\hline GPS position & $\begin{array}{l}62^{\circ} 48^{\prime} 26,4 \mathrm{~S} \\
058^{\circ} 28^{\prime} 53,9 \mathrm{~W}\end{array}$ & $\begin{array}{l}62^{\circ} 48^{\prime} 25,2 \mathrm{~S} \\
058^{\circ} 28^{\prime} 50,1 \mathrm{~W}\end{array}$ & $\begin{array}{l}62^{\circ} 10^{\prime} 02,3 \mathrm{~S} \\
058^{\circ} 2740,9 \mathrm{~W}\end{array}$ & $\begin{array}{l}62^{\circ} 09^{\prime} 23,2 \mathrm{~S} \\
058^{\circ} 28^{\prime} 20,2 \mathrm{~W}\end{array}$ & $\begin{array}{l}62^{\circ} 09^{\prime} 37,0 \mathrm{~S} \\
058^{\circ} 28^{\prime} 23,7 \mathrm{~W}\end{array}$ \\
\hline Elevation. (m a.s.1.) & 8 & 7 & 9 & 227 & 225 \\
\hline Area $\left(\mathrm{m}^{2}\right)$ & & 266.91 & 122.30 & 117.60 & 123.80 \\
\hline $\mathrm{NH}_{4}-\mathrm{N}\left(\mathrm{mg} \mathrm{l}^{-1}\right)$ & $0.024( \pm 0.004)$ & $0.035( \pm 0.011)$ & $0.426( \pm 0.071)$ & $0.161( \pm 0.018)$ & $0.033( \pm 0.002)$ \\
\hline $\mathrm{PO}_{4}-\mathrm{P}\left(\mathrm{mg} \mathrm{l}^{-1}\right)$ & $0.148( \pm 0.003)$ & $0.130( \pm 0.00)$ & $0.120( \pm 0.042)$ & $0.079( \pm 0.02)$ & $0.154( \pm 0.044)$ \\
\hline P-tot $\left(\mathrm{mg} \mathrm{l}^{-1}\right)$ & $0.03( \pm 0.00)$ & $0.035( \pm 0.007)$ & $0.050( \pm 0.028)$ & $0.020( \pm 0.00)$ & $0.070( \pm 0.00)$ \\
\hline N-tot $\left(\mathrm{mg} \mathrm{l}^{-1}\right)$ & $0.650( \pm 0.071)$ & $1.950( \pm 1.768)$ & $4.100( \pm 0.00)$ & $1.400( \pm 0.00)$ & $1.700( \pm 0.00)$ \\
\hline $\mathrm{pH}\left(\mathrm{mg} \mathrm{l}^{-1}\right)$ & $7.6( \pm 0.5)$ & $7.7( \pm 0.6)$ & $8.4( \pm 0.7)$ & $6.5( \pm 1.2)$ & $7.1( \pm 0.8)$ \\
\hline temp $\left({ }^{\circ} \mathrm{C}\right)$ & $2.8( \pm 1.8)$ & $2.9(1.6)$ & $5.0( \pm 0.2)$ & $6.1( \pm 2.1)$ & $5.8( \pm 0.6)$ \\
\hline $\mathrm{O}_{2}\left(\mathrm{mg} \mathrm{l}^{-1}\right)$ & $11.85( \pm 0.35)$ & $10.40( \pm 0.42)$ & $10.86( \pm 1.22)$ & $11.08( \pm 0.60)$ & $10.92( \pm 0.23)$ \\
\hline Conductivity (uS/cm) & $79.4( \pm 26.86)$ & $84.7( \pm 41.37)$ & $166.1( \pm 76.23)$ & $135.0( \pm 32.85)$ & $160.3( \pm 19.38)$ \\
\hline Chlorophyll a $\left(\mu \mathrm{g}^{-1}\right)$ & 0.400 & 0.417 & 1.666 & 0.900 & 0.900 \\
\hline Pheophytin $\left(\mu \mathrm{g} 1^{-1}\right)$ & 2.800 & 2.791 & 2.125 & 3.800 & 1.800 \\
\hline Total chlorophyll $\left(\mu \mathrm{g}^{-1}\right)$ & 3.200 & 3.208 & 3.791 & 4.700 & 2.700 \\
\hline $\mathrm{DOC}\left(\mathrm{mg} \mathrm{l}^{-1}\right)$ & 0.567 & 0.653 & 1.135 & 0.787 & 0.826 \\
\hline
\end{tabular}

stream. They were located in the foreland of Ecology Glacier near to the Polish Antarctic Station "Arctowski" (King George Island, West Antarctica) (Fig. 1).

Selected reservoirs were different in age, location, and environmental parameters (Table 1). Located near to the front of Ecology Glacier, pond 7 was two years old. This reservoir was located on the ground moraine and was directly supplied with water from the glacier, with no signs of vegetation. Stream 6 is receiving water flowing directly from the glacier. Pond 8 was located away from the front of the glacier, with abundant bloom of microalgae. Reservoirs 10 and 11 , which have been noticed there since 1977 , were situated on the top of lateral moraine. Both were situated close to each other and connected with small stream (Fig. 1). Samples were taken with a sampler on a bracket into sterile bottles and delivered to the laboratory within 1 hour. Microbial mat samples were collected as cores $(1 \times 5 \mathrm{~cm})$, and one gram of sample was aseptically weighed and homogenized in $9 \mathrm{ml}$ of sterile cold. $\left(4^{\circ} \mathrm{C}\right)$ physiological saline $(0.86 \% \mathrm{NaCl})$ using a vortex. Cultures were obtained by plating $100 \mu \mathrm{l}$ of a sample onto Antarctic Bacteriological Medium (ABM; pH 7.4) containing: peptone $(0.5 \%, \mathrm{w} / \mathrm{v})$, yeast extract $(0.2 \%, \mathrm{w} / \mathrm{v})$, and agar $(2 \%, w / v)$ in three replicates. Plates were incubated at $10{ }^{\circ} \mathrm{C}$ for 14 days. The well -separated colonies on medium were macroscopically described, photographed, than isolated under binocular, and transferred to slants of ABM in the tubes. After transportation to Poland the microscopic purity evaluation of Gram-stained strains was done.
Molecular Biology Procedures

In order to obtain DNA, cells were scraped from the surface of slants and washed in sterile water. DNA extraction was performed using commercial kit Genomic Mini (A\&A Biotechnology) according to the manufacturers' instructions. The purified DNA was suspended in $50 \mu \mathrm{l}$ of deionized, DNase free water and stored in $-20{ }^{\circ} \mathrm{C}$. The partial $16 S$ rRNA gene was amplified using the primers 341: 5'-CCTACGGGAGGCAGCAG - $3^{\prime}$ [15] and 16SR: 5'TACCTTGTTACGACTTCACCCCA-3' described previously by Rossau et al. [21]. In order to detect microorganism producing PHAs, PCR was performed with two primer pairs. First one, recognizing both scl- and mcl-PHA synthase genes was elaborated by Romo et al. [22] ( $G-D$ : 5'-GTGCCGCC(GC)(CT) (AG)(GC)ATCAACAAGT-3'; G1-R: $5^{\prime}$ GTTCCAG(AT)ACAG(GC)A(GT)(AG) TCG AA- $\left.3^{\prime}\right)$. The second primers pair (I-179L: 5'-ACAG ATCAACAAGTTCTACATCTT CGAC-3'; I-179R: 5'GGTGTTGTCGTTGTTCCAGTAGAGGATGTC- $3^{\prime}$ ) was specific for both genes responsible for mcl-PHA synthesis [25]. PCR was performed in Eppendorf ${ }^{\circledR}$ Mastercycler Gradient (Eppendorf, Germany). The mixtures used for PCR amplification contained $50 \mathrm{ng}$ of extracted DNA, $0.5 \mu \mathrm{M}$ of each primer, $100 \mu \mathrm{M}$ of deoxynucleoside triphosphate (Promega, Winsconsin, USA), 1 U of Taq DNA polymerase (POLGEN, Poland), and $5 \mu$ of reaction buffer (500 mM KCl, pH 8.5; Triton X-100). PHA synthase gene fragment amplification was carried out using program given by the authors. The temperature program for $16 \mathrm{~S}$ 
$r R N A$ gene amplification was as follows: $94{ }^{\circ} \mathrm{C}$ for $5 \mathrm{~min}$; 30 cycles of denaturation at $94{ }^{\circ} \mathrm{C}$ for $30 \mathrm{~s}$, annealing at $54{ }^{\circ} \mathrm{C}$ for $30 \mathrm{~s}$, extension at $72{ }^{\circ} \mathrm{C}$ for $1 \mathrm{~min}$, and single final elongation at $72{ }^{\circ} \mathrm{C}$ for $5 \mathrm{~min}$. The PCR amplicons of $16 \mathrm{~S}$ rDNA and PHA synthase genes were resolved on $1.5 \%$ agarose gels stained with ethidium bromide, and size of PCR products was estimated using molecular weight marker (100 bp, Promega, Winsconsin, USA). The sequencing of $16 \mathrm{~S}$ rDNA and scl-PHA synthase (phaC) PCR products was performed using the same PCR primers as for amplification. Because PCR primers pair $I-179 L$ and I-179R amplifies both genes coding for mcl-PHA synthase, we use primers orf2 (5'-CATGACAGCGGCCTGTTCAC CTGG- $3^{\prime}$ [5] ) and $I-179 R$ [25] using the same conditions as described in the work of Ciesielski et al. [5]. Using this approach, it was possible to amplify and directly sequence a fragment of phaC gene about $720 \mathrm{bp}$ long. DNA sequencing was performed using a Perkin Elmer ABI 373 Automated DNA Sequencer (PE Applied Biosystems, Foster City, CA, USA) at the Institute of Biochemistry and Biophysics in Warsaw, Poland. All reactions were run following the manufacturer's protocols. The nucleotide sequences were submitted to the GenBank database under accession numbers from KF301568 to KF301599.

\section{Phylogenetic Analysis}

The sequences of genes coding for 16S rRNA and PHA synthases were compared with those from the GenBank database using the NCBI blast program. Sequences were aligned using the ClustalW program [30]. The evolutionary distances were inferred using the Neighbor-Joining method [23] with the MEGA5 program [27]. To determine the degree of statistical support for branches in the phylogeny, 1,000 bootstrap replicates of data were analyzed. The gene sequences that were $>94.0 \%$ identical to sequences of cultured species in the NCBI database were assigned genus names [26].

\section{Statistics}

A canonical correspondence analysis (CCA) was conducted using a statistical package for Windows v. Canoco 4.5 [29]. The presence of bacteria possessing specific form of PHA synthase genes was analyzed in relation to the environmental background 'all other data'.

\section{Results}

A total of 50 bacterial isolates from five ponds and one stream were characterized by sequencing of $1000 \mathrm{bp}$ long fragment of $16 \mathrm{~S}$ rRNA gene. Twenty, unique DNA sequences were phylogenetically analyzed altogether with their closest relatives derived from GenBank (Fig. 2). Isolated strains belonged mainly to the phylum of Proteobacteria and represent classes Betaproteobacteria (11 isolates), Gammaproteobacteria (7 isolates), Alphaproteobacteria (2 isolates) and only two isolates belonged to Bacteroidetes phylum (Fig. 2). Nineteen strains were isolated from ponds and only one (Pseudomonas sp. P45) from stream in the foreland of Ecology Glacier. The highest number of strains were derived from pond 10 .

The most frequently recovered group of isolates was members of the Pseudomonas genus (7 isolates). Among them two strains (Pseudomonas sp. P5 and Pseudomonas sp. P45) possessed the same DNA sequence of studied $16 \mathrm{~S}$ rRNA gene fragments. The second numerous group of isolates belonged to Janthinobacterium genus (5 isolates).

In the aim of detection of a microorganism possessing the potential ability of PHAs synthesis, PCR was performed with two primers pairs. The first one $(G-D$ and $G-1 R)$, is able to recognize both scl- and mcl-PHA synthase genes [22]. The second primers pair $(I-179 L$ and $I-179 R)$ was specific only for mcl-PHA synthase genes [25]. The amplification using primers $G-D$ and $G-1 R$ gave a positive signal in 12 of the isolates corresponding to six pseudomonads strains, four Janthinobacterium strains, and two undefined Betaproteobacteria (P21 and P25). The obtained PCR amplicons possessed the expected length of $551 \mathrm{bp}$. The amplification with PCR primers designed by Solaiman and co-workers [25] showed that six Pseudomonas strains (P1, P4, P19, P27, P32, and P45) and two Janthinobacterium strains (P10 and P24) possessed genes responsible for mcl-PHA synthesis. PCR products obtained by employing primer pairs $G-D: G-1 R$ and orf $2: I-179 R$ were directionally sequenced.

The results of DNA sequencing of PCR products obtained using $G-D$ and $G-1 R$ primers proved that studied DNA of two Janthinabacterium strains (P38 and P39), and two undefined Betaproteobacteria strains (P21 and P25) is responsible for scl-PHA synthesis. Nucleotide composition of PCR products amplified with orf $2: I-179 R$ primers pair has provided evidence that all are typical for phaCl gene coding for synthase responsible for mcl-PHA synthesis. For deeper analysis, all obtained DNA sequences of phaC and phaCl genes, after division into two group, were phylogenetically examined altogether with their closest relatives found in GenBank. Evolutionary tree presenting genetic distance between phaC gene DNA sequences is shown in the Fig. 3. In the phaC gene group (scl-PHA) very high similarity (genetic distance 0.236 ) was revealed between Janthinobacterium sp. P39 and Antarctic Proteobacterium P21, inhabiting the same pond 7. Very close to them DNA sequence of Janthinobacterium sp. P38 was placed, and all three sequences obtained in this study were accompanied by DNA sequence of Zooglea ramigera. The fourth sequence, belonging to Antarctic Proteobacterium P25 was 


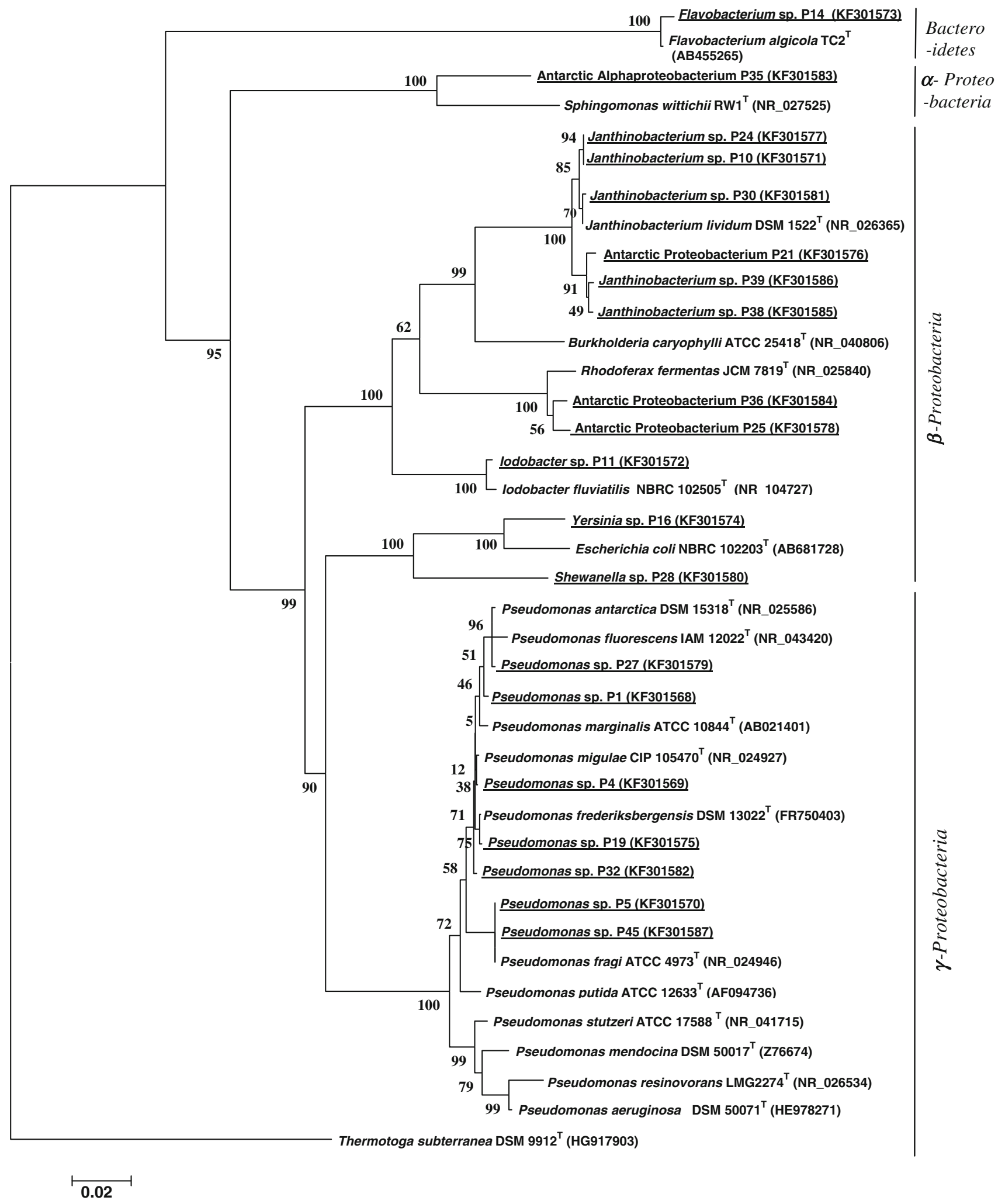

Fig. 2 Phylogenetic tree based on 16S rRNA sequences, generated by the neighbor-joining method showing the genetic relationships among bacteria analyzed in this work. Thermotoga subterranea (Acc. no HG917903) was selected as the outgroup. Type strains are indicated with superscript $\mathrm{T}$. The numbers on the branches refer to bootstrap values for 1,000 times. Accession numbers of DNA sequences are given in parentheses 


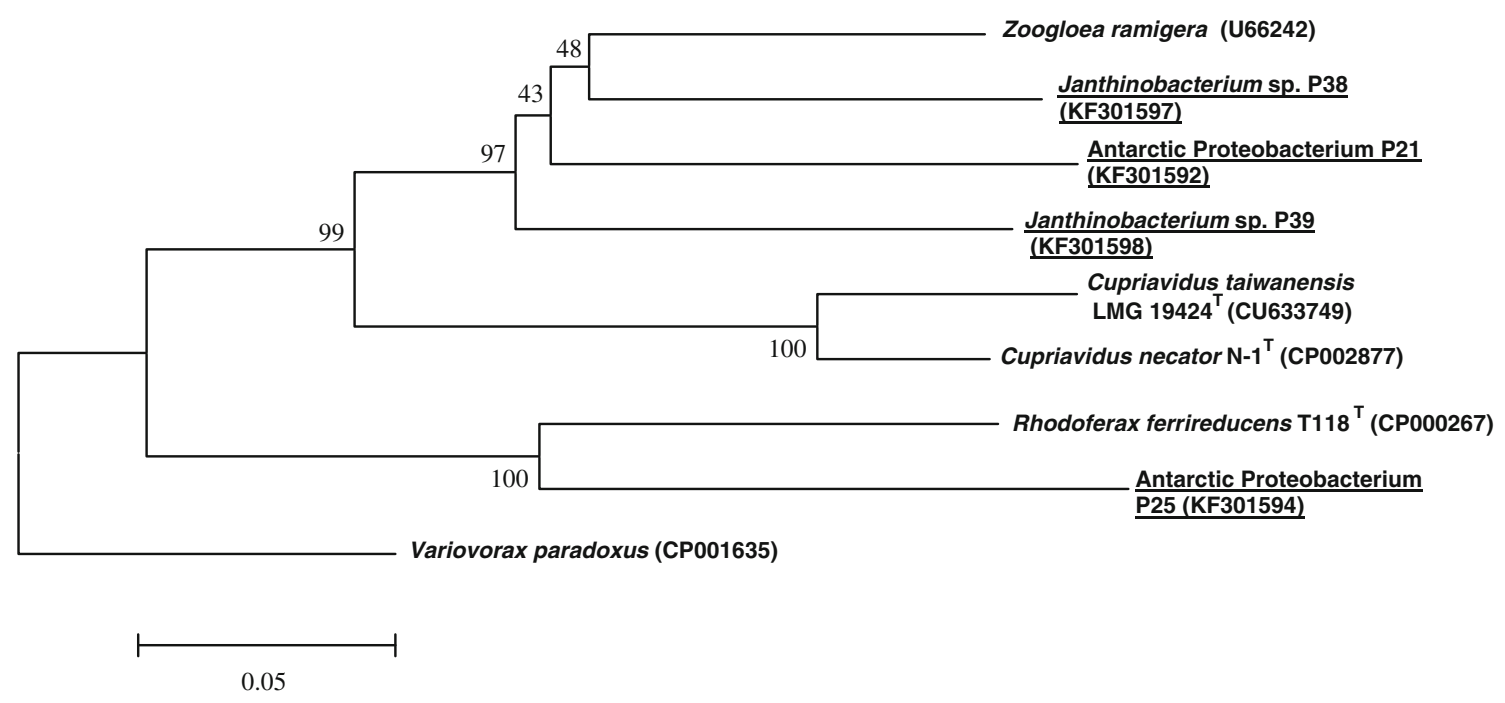

Fig. 3 Phylogenetic tree based on phaC gene coding for scl-PHA synthase, generated by the neighbor-joining method showing the genetic relationships among bacteria analyzed in this work. Variovorax paradoxus (Acc. no CP001635) was selected as the outgroup.

grouped with Rhodoferax ferrireducens (genetic distance 0.237) (Fig. 3). The second group, collecting DNA sequences of phaCl gene (mcl-PHA), was predominated by members of Pseudomonas species. The highest similarity (genetic distance 0.003), was observed between Pseudomonas sp. P1 and Pseudomonas sp. P4, both inhabiting the mat from lake 10 . The next pair, revealing high identity, was composed of Janthinobacterium sp. P10 and Pseudomonas sp. P19 (genetic distance 0.009) and was collected from different, although neighboring ponds. Surprisingly, these two sequences were grouped together with Janthinobacterium sp. P24 sequence that came also from mat of pond 10 . The rest of studied phaCl gene sequences were dispersed among sequences derived from GenBank. The most diverged phaCl gene sequence belonged to Pseudomonas sp. P45 that came from the glacier outlet stream (Fig. 4). Bacterial strains possessing genes phaC and phaCl are characterized in Table 2.

The statistical analysis of principal components (CCA) showed correlation between the presence of bacteria possessing particular PHA synthase gene and environmental conditions. Bacteria having genetic potential to synthesize scl-PHA inhabited reservoirs with rather low trophy characterized by low levels of total phosphorus and high amounts of pheophytins (Fig. 5).

\section{Discussion}

In the ponds that were studied, more than half of the isolated strains possessed genes responsible for PHAs
Type strains are indicated with superscript $\mathrm{T}$. The numbers on the branches refer to bootstrap values for 1,000 times. Accession numbers of DNA sequences are given in parentheses

synthesis. Among them were mainly microbes belonging to the Pseudomonas genus (six strains) and Janthinobacterium genus (four strains). Our results are in concordance with results of Goh and Tan [8]. They isolated from Antarctic soil strains of bacteria having the ability to produce PHAs, among them twelve were belonging to Pseudomonas spp. and three to Janthinobacterium genus. The presence of Janthinobacterium spp. in Antarctic waters has previously been discussed [28]. Shivaji et al. [24] showed that strains of this genus isolated from Antarctica could be divided into two groups; the first is "Jantinobacterium lividum group," whereas the second was called "atypical $J$. lividum group." Our analysis also indicates that isolated Janthinobacterium strains were divided into two groups on the base of gene coding for $16 S$ rRNA (Fig. 2). Like Janthinobacterium genus members, bacteria belonging to Pseudomonas spp. are often isolated from cold environments and are known for their metabolic versatility and high genome plasticity [18]. The possibility of PHAs accumulation and high tolerance to cold and oxidative stress is common features of many Pseudomonas species. Therefore, it is suggested that PHA metabolism in Antarctic strains could be an adaptation mechanism that is necessary to withstand hard conditions in polar regions [2].

The high number of isolates possessing genes responsible for PHAs synthesis suggests that Antarctic bacteria evolved, or obtained in another way, this metabolic ability to endure the extreme conditions typical for polar regions. Accordingly to our results, isolated strains possessed genes responsible for scl- or mcl-PHA synthesis. It is worth pointing out that bacteria having phaCl genes were 


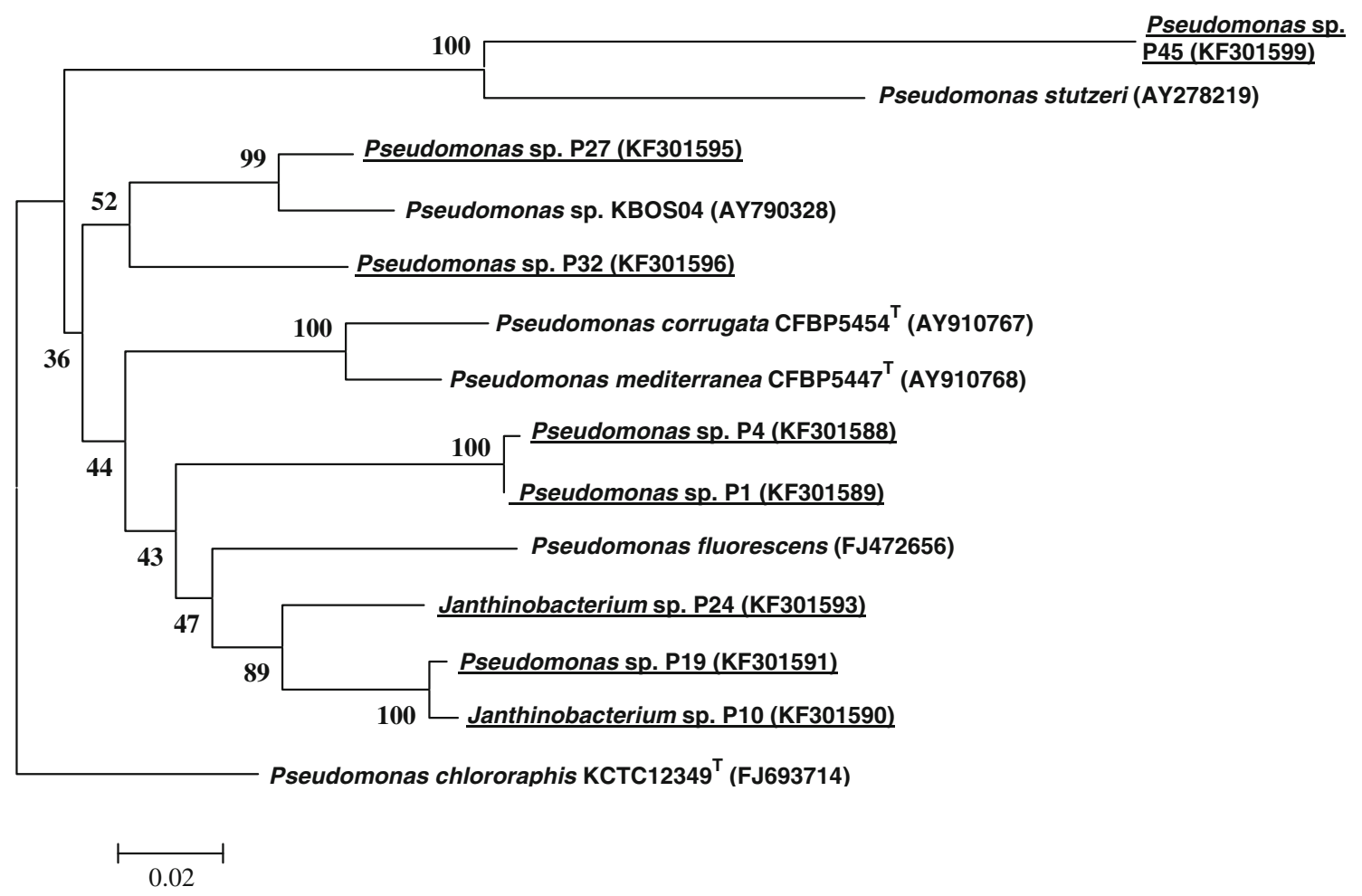

Fig. 4 Phylogenetic tree based on phaCl gene coding for mcl-PHA synthase, generated by the neighbor-joining method showing the genetic relationships among bacteria analyzed in this work. Pseudomonas chlororaphis KCTC12349 (Acc. no FJ693714) was selected as

isolated both from mats and water, and those having phaC gene were only planktonic. It has previously been reported that survival in harsh conditions can be increased by belonging to a complex communities like microbial mats [16]. Recent studies have evaluated the potential of microbial mats as high-level PHA production systems under natural conditions, and as a source of bacterial PHA producers $[3,13]$. Accordingly to these studies, microorganisms inhabiting microbial mats from marine coastal zones are able to synthesize and accumulate high quantities of PHAs. Our results also show that microbial mats created in Antarctic ponds could be a potential source of PHA producing bacteria.

Our comparative analysis of DNA sequences of $16 \mathrm{~S}$ rDNA and phaC/phaCl genes suggested that some strains possess PHA synthesis genes that might have not been obtained by gradual evolution. The best example are isolates belonging to Janthinobacterium spp. Among four members of this genus, possessing genes responsible for PHAs synthesis, two of them had phaC genes, whereas two had phaCl genes. The phaC gene of Janthinobacterium spp. P38 and P39 was similar to a variant of this gene previously detected only in Zooglea ramigera, whereas the phaCl genes of Janthinobacterium sp. P10 and P24 were the outgroup. Type strains are indicated with superscript T. The numbers on the branches refer to bootstrap values for 1,000 times. Accession numbers of DNA sequences are given in parentheses

most similar to genes of Pseudomonas fluorescences. The genes responsible for scl-PHA synthesis differ so much from those responsible for mcl-PHA synthesis that their presence in these closely related bacteria is most likely not the result of gradual evolution, but rather of horizontal gene transfer. It is interesting that isolates that had obtained these particular types of genes were divided into two subgroups on the basis of $16 \mathrm{~S} r D N A$ sequences (Fig. 2). It is possible that this evolutionary separation is related to some physiological differences that make a particular PHA operon useful for these bacteria. Previously, only scl-PHA producing Janthinobacterium spp. have been reported [8], and ours is the first report of potential mcl-PHA synthesis by members of this genus.

We found genes coding for mcl-PHA synthase mainly in Pseudomonas species. 16S rDNA gene analysis showed that the taxonomic position of each of the six Pseudomonas isolates having the phaCl gene was different (Table 2). Whereas, variation between phaCl genes was lower, closest DNA sequences of $\mathrm{phaCl}$ gene of examined strains obtained by BLAST searching belonged only to three genera. The DNA sequences of P1, P4, and P19 were closest to the sequence of Pseudomonas fluorescens, a well-known mcl-PHA producer [6]. The structure of the 
Table 2 Molecular identification of isolated strains, their nearest neighbors based on $16 \mathrm{~S} r R N A$ and phaC/phaCl genes and their isolation location

\begin{tabular}{|c|c|c|c|c|}
\hline Isolate & $\begin{array}{l}\text { Putative } \\
\text { PHA }\end{array}$ & $\begin{array}{l}\text { Closest relatives based on } 16 S \text { rDNA } \\
\text { sequence (Accession no/identity } \%)^{*}\end{array}$ & $\begin{array}{l}\text { Closest cultured based on phaC/phaCl } \\
\text { gene sequence (Accession no/identity } \\
\%)^{*}\end{array}$ & $\begin{array}{l}\text { Isolation } \\
\text { source }\end{array}$ \\
\hline Pseudomonas sp. P1 & $\mathrm{Mcl}$ & $\begin{array}{l}\text { Pseudomonas extremaustralis SY11 } \\
\text { (KC790323/99) }\end{array}$ & $\begin{array}{l}\text { Pseudomonas fluorescens } \text { Pf0-1 } \\
\quad \text { (CP000094/91) }\end{array}$ & $\begin{array}{l}\text { Mat (pond } \\
10)\end{array}$ \\
\hline Pseudomonas sp. $\mathrm{P} 4$ & $\mathrm{Mcl}$ & $\begin{array}{l}\text { Pseudomonas frederiksbergensis } \\
\quad \text { (JF343187/100) }\end{array}$ & $\begin{array}{l}\text { Pseudomonas fluorescens } \text { Pf0-1 } \\
\text { (CP000094/90) }\end{array}$ & $\begin{array}{l}\text { Mat (pond } \\
10 \text { ) }\end{array}$ \\
\hline Pseudomonas sp. P19 & $\mathrm{Mcl}$ & Pseudomonas putida C14 (JN228297/99) & $\begin{array}{l}\text { Pseudomonas fluorescens BM07 } \\
\quad \text { (FJ472656/91) }\end{array}$ & $\begin{array}{l}\text { Water (pond } \\
\text { 11) }\end{array}$ \\
\hline Pseudomonas sp. P27 & $\mathrm{Mcl}$ & Pseudomonas antarctica (HE586386/99) & $\begin{array}{l}\text { Pseudomonas fluorescens SBW25 } \\
\text { (AM181176/95) }\end{array}$ & $\begin{array}{l}\text { Water (pond } \\
8 \text { ) }\end{array}$ \\
\hline Pseudomonas sp. P32 & $\mathrm{Mcl}$ & Pseudomonas putida (HE586397/99) & $\begin{array}{l}\text { Pseudomonas sp. KBOS04 (AY790328/ } \\
\text { 92) }\end{array}$ & $\begin{array}{l}\text { Water (pond } \\
8 \text { ) }\end{array}$ \\
\hline Pseudomonas sp. $\mathrm{P} 45$ & $\mathrm{Mcl}$ & Pseudomonas fragi (AB685634/100) & $\begin{array}{l}\text { Pseudomonas stutzeri } 1317 \text { (AY278219/ } \\
\text { 84) }\end{array}$ & Stream 6 \\
\hline Janthinobacterium sp. P10 & $\mathrm{Mcl}$ & $\begin{array}{l}\text { Janthinobacterium lividum (HQ824865/ } \\
\text { 100) }\end{array}$ & $\begin{array}{l}\text { Pseudomonas extremaustralis } \\
\text { (FN435843/90) }\end{array}$ & $\begin{array}{l}\text { Water (pond } \\
10 \text { ) }\end{array}$ \\
\hline Janthinobacterium sp. P24 & $\mathrm{Mcl}$ & $\begin{array}{l}\text { Janthinobacterium lividum (HQ824864/ } \\
\text { 100) }\end{array}$ & $\begin{array}{l}\text { Pseudomonas fluorescens BM07 } \\
\quad \text { (FJ472656/92) }\end{array}$ & $\begin{array}{l}\text { Mat (pond } \\
10)\end{array}$ \\
\hline $\begin{array}{l}\text { Antarctic } \\
\text { Betaproteobacterium P21 }\end{array}$ & Scl & Burkholderia sp. Era35(JQ977167/99) & Zooglea ramigera (U66242/83) & $\begin{array}{l}\text { Water (pond } \\
7 \text { ) }\end{array}$ \\
\hline $\begin{array}{l}\text { Antarctic } \\
\text { Betaproteobacterium P25 }\end{array}$ & $\mathrm{Scl}$ & Rhodoferax ferrireducens (HG003356/99) & $\begin{array}{l}\text { Comamonas testosteroni CNB-2 } \\
\quad(\mathrm{CP} 001220 / 81)\end{array}$ & $\begin{array}{l}\text { Water (pond } \\
10 \text { ) }\end{array}$ \\
\hline Janthinobacterium sp. P38 & $\mathrm{Scl}$ & $\begin{array}{l}\text { Janthinobacterium sp. SMN } 33.6 \\
\text { (JX624164/99) }\end{array}$ & Zooglea ramigera (U66242/83) & $\begin{array}{l}\text { Water (pond } \\
10 \text { ) }\end{array}$ \\
\hline Janthinobacterium sp. P39 & $\mathrm{Scl}$ & $\begin{array}{l}\text { Janthinobacterium sp. TMT4-26-6 } \\
\text { (JX949991/99) }\end{array}$ & Zooglea ramigera (U66242/83) & $\begin{array}{l}\text { Water (pond } \\
\text { 7) }\end{array}$ \\
\hline Pseudomonas sp. P5 & - & Pseudomonas fragii (AB685683/99) & - & $\begin{array}{l}\text { Water (pond } \\
\text { 8) }\end{array}$ \\
\hline Iodobacter sp P11 & - & Iodobacter fluviatilis (KC213858/100) & - & $\begin{array}{l}\text { Water (pond } \\
7 \text { ) }\end{array}$ \\
\hline Flavobacterium sp. P14 & - & Flavobacterium algicola (AB455265/99) & - & $\begin{array}{l}\text { Water (pond } \\
10 \text { ) }\end{array}$ \\
\hline Yersinia sp. P16 & - & Yersinia intermedia (NR_027545/99) & - & $\begin{array}{l}\text { Water (pond } \\
7 \text { ) }\end{array}$ \\
\hline Shewanella sp. P28 & - & Shewanella putrefaciens (KC607503/99) & - & $\begin{array}{l}\text { Water (pond } \\
\text { 8) }\end{array}$ \\
\hline Janthinobacterium sp. P30 & - & $\begin{array}{l}\text { Janthinobacterium lividum (HQ824941/ } \\
\text { 99) }\end{array}$ & - & $\begin{array}{l}\text { Water (pond } \\
7 \text { ) }\end{array}$ \\
\hline $\begin{array}{l}\text { Antarctic } \\
\text { Alphaproteobacterium P35 }\end{array}$ & - & $\begin{array}{l}\text { Sphingomonadaceae bacterium N } \\
\text { (DQ497241/99) }\end{array}$ & - & $\begin{array}{l}\text { Water (pond } \\
\text { 7) }\end{array}$ \\
\hline $\begin{array}{l}\text { Antarctic } \\
\text { Betaproteobacterium P36 }\end{array}$ & - & $\begin{array}{l}\text { Rhodoferax ferrireducens (NR_074760/ } \\
\text { 99) }\end{array}$ & - & $\begin{array}{l}\text { Water (pond } \\
8 \text { ) }\end{array}$ \\
\hline
\end{tabular}

* Only cultured strains were considered during BLAST searching

phaCl gene of Pseudomonas sp. P27 was most similar to the gene of Pseudomonas sp. KBOS 04 isolated from activated sludge by Ciesielski et al. [4]. In the same study, the same PHA operon was found in both cells of Pseudomonas sp. KBOS04 and of Comamonas testosteroni. This observation may suggest that these PHA operons have been horizontally transferred between cells. Pseudomonas sp. $\mathrm{P} 45$, inhabiting a glacial melt water stream, possessed a
phaCl gene most similar to that of Pseudomonas stutzeri, although the similarity was only $84 \%$. It should be underlined that the nucleotide composition of the Pseudomonas sp. P45 16S rRNA gene was most similar to $P$. fragi and identical to the DNA sequence of the Pseudomonas sp. P5 isolated from pond 8. In contrast to Pseudomonas sp. P45, in cells of strain P5, genes responsible for PHA synthesis were not detected. In general, comparative analysis 


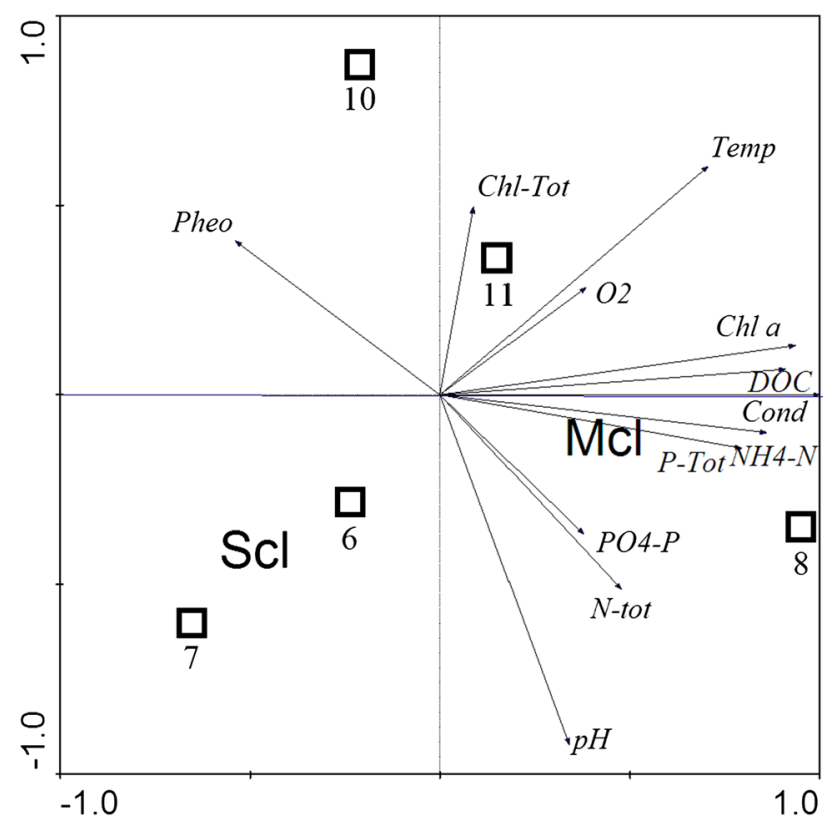

Fig. 5 Canonical correspondence analysis showing relation between the presence of bacteria possessing specific form of PHA synthase genes and environmental data of sampling sites

of $16 S$ rRNA and phaC/phaCl genes revealed that isolated bacteria gain the genetic ability to synthesize PHA rather as a result of horizontal gene transfer than by gradual evolution. Furthermore, it seems that some PHA operons are favored during this unusual ecological event.

Bacteria possessing PHA synthase coding genes were detected in each of the studied location suggesting that PHAs accumulation could increase the survival capabilities of microorganisms in this extreme environment. Bacteria having genes responsible for both scl- and mcl-PHAs synthesis were found, but those able of scl-PHA synthesis were discovered only in ponds 7 and 10 . These two reservoirs characterized with high amounts of pheophytin and total chlorophyll. The relation between the presence of scl-PHA producing bacteria and environmental conditions is supported by CCA (Fig. 5). The highest number of different forms of phaClphaCl genes was founded in pond 10 , which was characterized by low $\mathrm{pH}$ (6.5), highest level of pheophytin $\left(3.800 \mu \mathrm{g} \mathrm{l}^{-1}\right)$, and total chlorophyll $\left(4.700 \mu \mathrm{g}^{-1}\right)$, and with the highest temperature measured $\left(6.1^{\circ} \mathrm{C}\right)$. Only one strain having phaCl gene was isolated from pond 11 (Pseudomonas sp. P19) and what is interesting similar form of gene was found in cells of Janthinobacterium sp. P10 inhabiting pond 10 (Fig. 1). Ponds 10 and 11 are connected with the stream and it is likely, that this form of phaCl was channeled from pond 11 to pond 10. A very distant form of $\mathrm{phaCl}$ gene was found in the mat taken from the stream 6 , it might release from the fact that environmental conditions in the streams are different from those in ponds. The spatial distribution of microorganisms possessing particular form of genes in the area of glacier forefield results mainly from glacier melting. The flowing water carries not only nutrients and minerals, but also transfers microorganisms having accelerated ability to colonize new territories. This group can include bacteria having ability to utilize PHAs produced by themselves or other members of microbial community [11]. It seems that bacteria having genetic ability to store and degrade PHAs can work as a pioneers during a succession process. Thus, glacier forefields provide a unique opportunity as a natural laboratory to study the succession of microorganisms.

To sum up, our study shows that many microorganisms inhabiting freshwater lakes charged with glacier meltwater possess the genes responsible for PHA synthesis. Most of the strains possessing PHA synthase genes belonged to Pseudomonas and Janthinobacterium species. All isolated Pseudomonas species had the phaCl gene responsible for mcl-PHA synthesis, whereas Janthinobacterium isolates had phaC and phaCl genes used for both scl- and mcl-PHA synthesis. To our knowledge, this is the first evidence that Janthinobacterium spp. have the potential to synthesize mcl-PHAs. Another interesting observation is the lack of correspondence between the evolutionary history of the I6S rDNA genes and those coding for PHA synthases. Phylogenetic analyses of the phaC and phaCl genes, especially in Janthinobacterium sp., suggest that these genes could have been acquired by horizontal gene transfer. The obtained results allow us to speculate that the possession of these genes enabling PHA synthesis may improve the fitness and survival of bacteria in harsh conditions. Additionally, the presented results show that microorganisms inhabiting extreme environments should be considered as potential producers of PHAs.

Acknowledgments The study was financed under project no. N N304106940 of the Polish National Center for Science.

Open Access This article is distributed under the terms of the Creative Commons Attribution License which permits any use, distribution, and reproduction in any medium, provided the original author(s) and the source are credited.

\section{References}

1. Anderson AJ, Dawes EA (1990) Occurence, metabolism, metabolic role, and industrial uses of bacterial polyhydroxyalkanoates. Microbiol Rev 54:450-472

2. Ayub ND, Tribelli PM, López NI (2009) Polyhydroxyalkanoates are essential for maintenance of redox state in the Antarctic bacterium Pseudomonas sp. 14-3 during low temperature adaptation. Extremophiles 13:59-66

3. Berlanga M, Montero MT, Hernandez-Borrel J, Guerrero R (2006) Rapid spectrofluorometric screening of poly-hydroxyalkanoate-producing bacteria from microbial mats. Int Microbiol 9:95-102

4. Ciesielski S, Cydzik-Kwiatkowska A, Pokoj T, Klimiuk E (2006) Molecular detection and diversity of medium-chain-length 
polyhydroxyalkanoates producing bacteria enriched from activated sludge. J Appl Microbiol 101:190-199

5. Ciesielski S, Możejko J, Przybyłek G (2010) The influence of nitrogen limitation on mcl-PHA synthesis by two newly isolated strains of Pseudomonas sp. J Ind Microbiol Biotechnol 37:511-520

6. Choi MH, Xu J, Rho JK, Zhao XP, Yoon SC (2010) Enhanced production of longer side-chain polyhydroxyalkanoic acid with omega-aromatic group substitution in phaZ-disrupted Pseudomonas fluorescens BM07 mutant through unrelated carbon source cometabolism and salicylic acid beta-oxidation inhibition. Bioresour Technol 101:4540-4548

7. Dawes EA, Senior PJ (1973) The role and regulation of energy reserve polymers in micro-organisms. Adv Microb Physiol 10:135-266

8. Goh YS, Tan IKP (2012) Polyhydroxyalkanoate production by antarctic soil bacteria isolated from Casey Station and Signy Island. Microbiol Res 167:211-219

9. Gounot AM (1991) Bacterial life at low temperature: physiological aspects and biotechnological implications. J Appl Bacteriol 71:386-397

10. Hein S, Paletta JR, Steinbuchel A (2002) Cloning, characterization and comparison of the Pseudomonas mendocina polyhydroxyalkanoate synthases PhaCl and PhaC2. Appl Microbiol Biotechnol 58:229-236

11. Kadouri D, Jurkevitch E, Okon Y, Castro-Sowinski S (2005) Ecological and agricultural significance of bacterial polyhydroxyalkanoates. Crit Rev Microbiol 31:55-67

12. Knigth V, Sanglier JJ, DiTullio D, Bracelli S, Bonner P, Waters J, Hugnes D, Zhang L (2003) Diversifying microbial natural products for drug discovery. Appl Microbiol Biotechnol 62:446-458

13. López-Cortés A, Lanz-Landázuri A, García-Maldonado JQ (2008) Screening and isolation of PHB-producing bacteria in a polluted marine microbial mat. Microb Ecol 56:112-120

14. Madison LL, Huisman GW (1999) Metabolic engineering of poly(3-hydroxyalkanoates): from DNA to plastic. Microbiol Mol Biol Rev 63:21-53

15. Muyzer G, de Waal EC, Uitterlinden AG (1993) Profiling of complex microbial populations by denaturing gradient gel electrophoresis analysis of polymerase chain reaction-amplified genes encoding for 16S rRNA. Appl Environ Microbiol 59:695-700

16. Peimbert M, Alcaraz LD, Bonilla-Rosso G, Olmedo-Alvarez G, García-Oliva F, Segovia L, Eguiarte LE, Souza V (2012) Comparative metagenomics of two microbial mats at Cuatro Ciénegas basin I: ancient lessons on how to cope with an environment under severe nutrient stress. Astrobiology 12:648-658

17. Pudełko R (2008) Two new topographic maps for sites of scientific interest on King George Island, West Antarctica. Pol Polar Res 29:291-297

18. Reddy GS, Matsumoto GI, Schumann P, Stackebrandt E, Shivaji S (2004) Psychrophilic pseudomonads from Antarctica: Pseudomonas antarctica sp. nov., Pseudomonas meridiana sp. nov. and Pseudomonas proteolytica sp. nov. Int J Syst Evol Microbiol 54:713-719
19. Rehm BH, Steinbüchel A (1999) Biochemical and genetic analysis of PHA synthases and other proteins required for PHA synthesis. Int J Biol Macromol 25:3-19

20. Rehm BH (2003) Polyester synthases: natural catalysts for plastics. Biochem J 376:15-33

21. Rossau R, Duhamel M, Jannes G, Decourt JL, van Heuverswyn H (1991) The development of specific rRNA-derived oligonucleotide probes for Haemophilus ducreyi, the causative agent of chancroid. J Gen Microbiol 137:277-285

22. Romo DMR, Grosso MV, Solano NCM, Castaňo DM (2007) A most effective method for selecting a broad range of short and medium-chain-length polyhydroxyalkanoates producing microorganisms. Electron J Biotechnol 10:348-357

23. Saitou N, Nei M (1987) The neighbor-joining method: a new method for reconstructing phylogenetic trees. Mol Biol Evol 4:406-425

24. Shivaji S, Ray MK, Seshu Kumar G, Reddy GSN, Saisree L, Wynn-Williams DD (1991) Identification of Janthinobacterium lividum from the soils of the islands of Scotia Ridge and from Antarctic peninsula. Polar Biol 11:267-271

25. Solaiman DKY, Ashby RD, Foglia TA (2000) Rapid identification of medium-chain-length polyhydroxyalkanoate synthase gene by polymerase chain reaction. Appl Microbiol Biotechnol 53:690-694

26. Stackebrandt E, Goebel BM (1994) A place for DNA-DNA reassociation and 16S rRNA sequence analysis in the present species definition in bacteriology. Int J Syst Bacteriol 44:846-849

27. Tamura K, Peterson D, Peterson N, Stecher G, Nei M, Kumar S (2011) MEGA5: molecular evolutionary genetics analysis using maximum likelihood, evolutionary distance, and maximum parsimony methods. Mol Biol Evol 28:2731-2739

28. Tindall BJ, Brambilla E, Steffen M, Neumann R, Pukall R, Kroppenstedt RM, Stackebrandt E (2000) Cultivatable microbial biodiversity: gnawing at the Gordian knot. Environ Microbiol 72:310-318

29. ter Braak CJF, Šmilauer P (2002) CANOCO reference manual and CanoDraw for Windows user's guide: software for canonical community ordination (version 4.5). Microcomputer Power, Ithaca

30. Thompson JD, Higgins DG, Gibson TJ (1994) CLUSTAL W: improving the sensitivity of progressive multiple sequence alignment through sequence weighting, positions-specific gap penalties and weight matrix choice. Nucleic Acids Res 22:4673-4680

31. Quillaguamán J, Guzmán H, Van-Thuoc D, Hatti-Kaul R (2011) Synthesis and production of polyhydroxyalkanoates by halophiles: current potential and future prospects. Appl Microbiol Biotechnol 85:1687-1696

32. Witholt B, Kessler B (1999) Perspectives of medium chain length poly(hydroxyalkanoates), a versatile set of bacterial bioplastics. Curr Opin Biotechnol 10:2785-2792

33. Van den Burg B (2003) Extremophiles as a source for novel enzymes. Curr Opin Microbiol 6:213-218 